\title{
Editorial: Masking and Unmasking
}

In between dancing for Diaghilev and establishing British ballet, Ninette de Valois collaborated with W.B. Yeats in Dublin. This was the time when Yeats was putting on his Japanese-style plays, with the actors wearing masks, and de Valois acting in some of these productions.

In her copy of The King of the Great Clock Tower Yeats wrote the following dedication: 'To Ninette de Valois asking pardon for covering her expressive face with a mask.'

It could be argued that the name Ninette de Valois itself was a mask, for its owner was actually Edris Stannus, from County Wicklow in Ireland. But after being theatrically re-christened by Diaghilev, she certainly became Ninette de Valois, a figure of considerable force in British artistic life, though never entirely losing her Irishness.

Yeats covered an expressive face with a mask. By contrast, Matisse, another of the twentieth century's greatest visionaries, used masks to reveal, or so we are told. Matisse was early on struck by the power of the African masks he had seen in Paris before the First World War. In the portraits he subsequently painted, the faces of the sitters are to all intents and purposes masks. For Matisse and his admirers these masks revealed expression and character in a way a realistic representation could not. The expressive face was not covered, but shown forth. His masks, we are asked to consider, unmasked.

Is there a paradox here, philosophically speaking, the mask at one level covering, at another revealing? It must be said that on the surface the African masks which inspired Matisse and the mask which covered de Valois's expressive face do not seem to reveal the character behind. But this may be because they have been devised for a different purpose, to present another character than that of the wearer of the mask, a role the wearer adopts for a time and for a specific purpose.

Matisse's genius, if such it was, was to understand that in their simplicity and directness there could be masks which reveal what most of us work to hide beneath the surface appearance of our skin. What the face hides, a mask can uncover. Yeats asked pardon for a mask which covered; Matisse might have asked pardon for masks which stripped appearance away. 